significantly $(\mathrm{p}<0.01)$ improved DMG (786 vs $751 \mathrm{~g})$ and $\mathrm{CR}(2.80$ vs 2.89$)$. Whey intake improved DMG (787 vs $750, p<0.01)$. Improvement of the gain was all the more marked as the feed was pelleted ( 821 vs $754 \mathrm{~g})$ and the whey intake was low (12.5 vs $17.7 \mathrm{p}$. 100), as compared to pigs fed the diet in the form of meal ( $752 \mathrm{vs} 748 \mathrm{~g}$ ) and water only. Increase in the dietary cellulose content led to a significant reduction $(p<0.01)$ in the carcass adiposity and to an increase in muscle quantity in relationship with a decreased growth rate. Feed pelleting and whey supplementation did not affect carcass quality, although an increased flare fat deposition was observed in pigs fed whey.

In a total digestibility trial, 24 pigs were distributed into 6 groups and 4 replicates according to a factorial design $3 \times 2$. Three levels $(2.5,4.5$ and $6.5 \mathrm{p} .100)$ of crude fibre (wheat bran) were combined to the absence or presence of whey at a level of $30 \mathrm{p} .100$ of dietary DM. The same combination was studied for ileal digestibility in six pigs fitted with an ileo-rectal anastomosis, using a latin square design. The apparent digestibility coefficients (aDC) of all dietary nutrients were significantly reduced $(p<0.01)$ by the increase in the cellulose content : by 4 points for energy for 1 p. 100 crude fibre, but the presence of 30 p. 100 whey also provoked an additional reduction by 4 points. However, significant interactions only occurred between these factors for cell-wall constituents. Digestibility of the lignin-cellulose fraction, and at a lesser extent that of hemicelluloses was lower in cellulose-poor diets than in the others. The difference between total and ileal aDC for each diet was generally positive, except for lipids. However, the magnitude of the difference varied according to the diets : from 4 points for energy with cellulose-poor diets with water up to 13 points for whey-rich diets.

\title{
Evaluation of wet brewers' yeast in diets for bacon pigs
}

\section{J. CHAUVEL ${ }^{(1)}$, R. GRANIER ${ }^{(2)}$}

(1) Institut Technique du Porc, Domaine de la Motte-au-Vicomte, B.P. 3, 35650 Le Rheu (2) Station Expérimentale Les Cabrières, 12200 Villefranche-de-Rouergue

Two trials were made to assess the performance of bacon pigs fed wet brewers' yeast. In both trials, the absence or the presence of yeast was tested. In the first trial, yeasts accounted for $\mathbf{9} \mathbf{p}$. 100 of DM in a diet including whey and 16 p. 100 in the second one. Each trial involved 160 animals, i.e. 80 animals per treatment. In both trials, the diet was given according to a progressive and continuous feeding scheme until a maximum level of $8,200 \mathrm{Kcal} \mathrm{DE}$ for castrated males and $9,300 \mathrm{Kcal}$ for females. A maximum of $1,7 \mathrm{l}$ of yeast was given in the first trial and 2,8 1 in the second one.

Incorporation of yeasts improved the fattening performance (growth rate and feed conversion ratio) by 6 p. 100 in the first trial and 8 p. 100 in the second one as well in females as in castrated males.

It was concluded that steam-killed wet brewers' yeast with a minimum dry matter content of $130 \mathrm{~g} / \mathrm{l}$ may supply 50 p. 100 of protein supplementation.

\section{Monosodium glutamate supplementation of pig starters}

\author{
F. GATEL ${ }^{(1)}$, G. BURON ${ }^{(1)}$, P. GUION ${ }^{(2)}$, J. FEKETE ${ }^{(1)}$
}

(1) Institut Technique des Céréales et Fourrages, 8, avenue du Président-Wilson, 75116 Paris

(2) Société ORSAN, 16, rue Ballu, 75009 Paris

In intensive management conditions, it is recommended to give starter feeds to piglets from the first days of age in order to improve post-weaning performance. Palatability of the starter feed is important to insure adequate consumption of the required nutrients. The monosodium glutamate 